
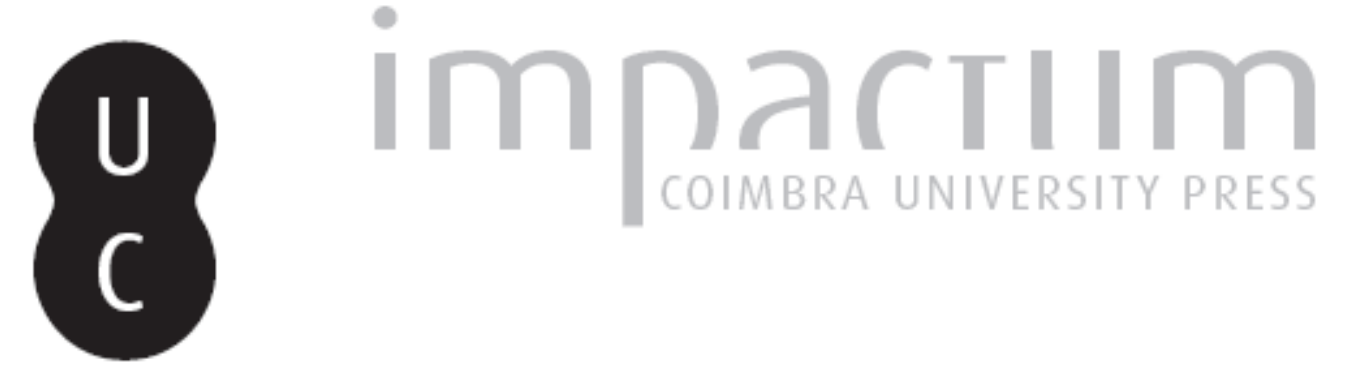

\title{
High resolution fire hazard index based on satellite images
}

Autor(es): $\quad$ Laneve, Giovanni; Fusilli, Lorenzo

Publicado por: Imprensa da Universidade de Coimbra

URL persistente:

URl:http://hdl.handle.net/10316.2/46127

DOI:

DOI:https://doi.org/10.14195/1647-7723_26-1_3

Accessed : $\quad$ 26-Apr-2023 12:01:57

A navegação consulta e descarregamento dos títulos inseridos nas Bibliotecas Digitais UC Digitalis, UC Pombalina e UC Impactum, pressupõem a aceitação plena e sem reservas dos Termos e Condições de Uso destas Bibliotecas Digitais, disponíveis em https://digitalis.uc.pt/pt-pt/termos.

Conforme exposto nos referidos Termos e Condições de Uso, o descarregamento de títulos de acesso restrito requer uma licença válida de autorização devendo o utilizador aceder ao(s) documento(s) a partir de um endereço de IP da instituição detentora da supramencionada licença.

Ao utilizador é apenas permitido o descarregamento para uso pessoal, pelo que o emprego do(s) título(s) descarregado(s) para outro fim, designadamente comercial, carece de autorização do respetivo autor ou editor da obra.

Na medida em que todas as obras da UC Digitalis se encontram protegidas pelo Código do Direito de Autor e Direitos Conexos e demais legislação aplicável, toda a cópia, parcial ou total, deste documento, nos casos em que é legalmente admitida, deverá conter ou fazer-se acompanhar por este aviso.

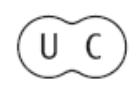




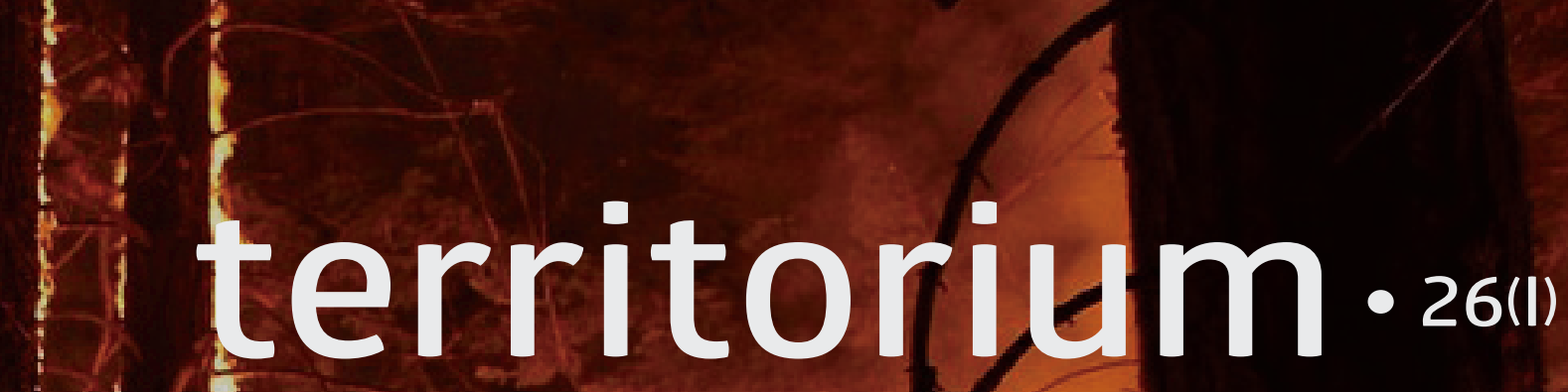

1 REVISTA Internacional de RIsCos I International JOURNAL OF RISKS
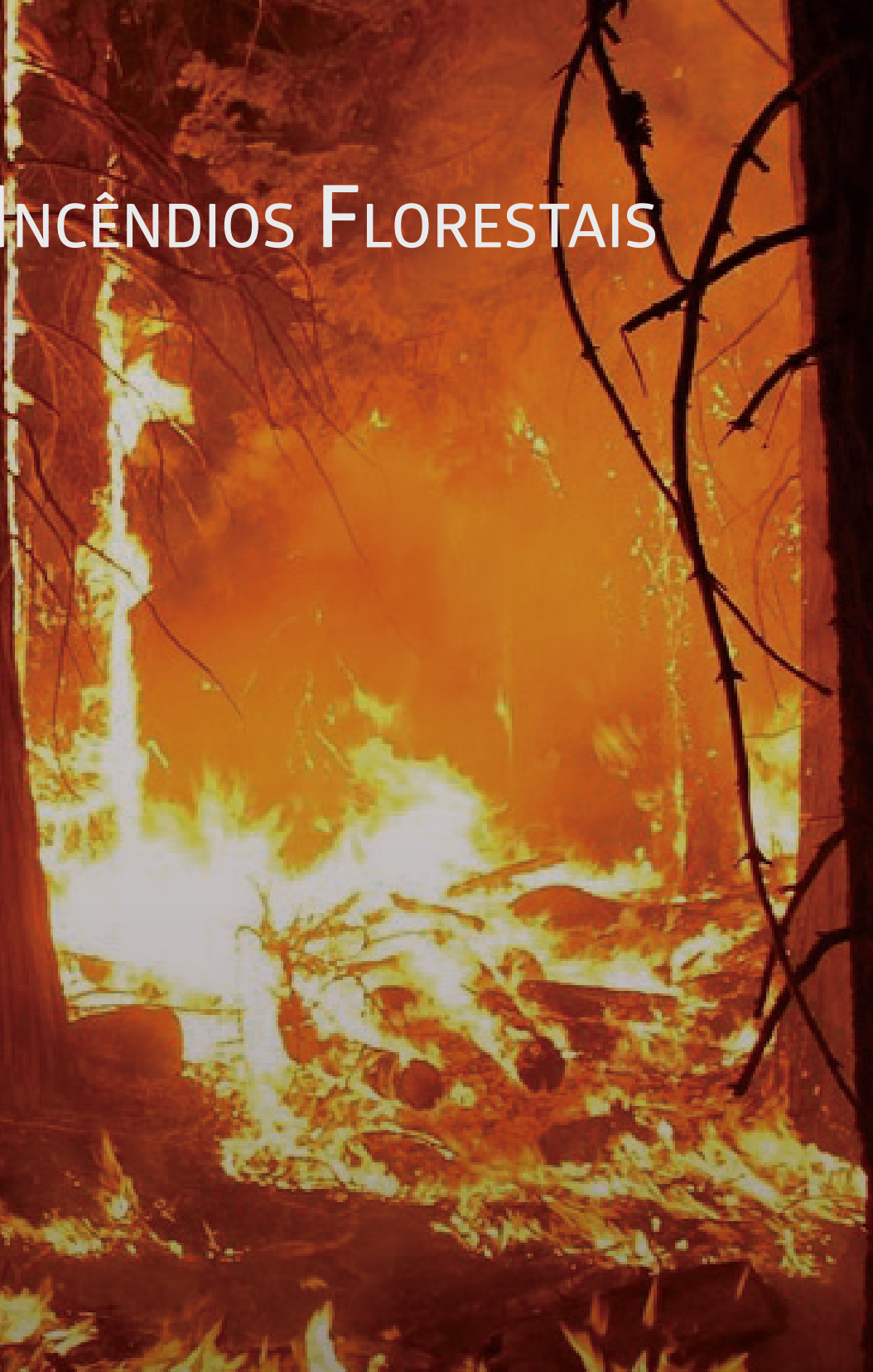

sec

Imprensa da Universidade de Coimbra Associação Portuguesa de Riscos, Prevenção e Segurança 


\title{
HIGH RESOLUTION FIRE HAZARD INDEX BASED ON SATELLITE IMAGES*
}

ÍNDICE DE RISCOS DE INCÊNDIO DE ALTA RESOLUÇÃO COM BASE EM IMAGENS SATÉLITES

Giovanni Laneve

Dipartimento di Ingegneria Astronautica, Elettrica e Energetica, Universidade de Roma "La Sapienza" (Italy) ORCID 0000-0001-6108-9764 giovanni.laneve@uniroma1.it

Lorenzo Fusilli

Dipartimento di Ingegneria Astronautica, Elettrica e Energetica, Universidade de Roma "La Sapienza" (Italy) ORCID 0000-0001-9912-7332 lorenzo.fusilli@uniroma1.it

\begin{abstract}
In December 2015, after 3 year of activity, the FP7 project PREFER (Space-based Information Support for Prevention and REcovery of Forest Fires Emergency in the MediteRranean Area) came to an end. The project was designed to respond to the need to improve the use of satellite images in applications related to the emergency services, in particular, to forest fires. The project aimed at developing, validating and demonstrating information products based on optical and SAR (Synthetic Aperture Radar) imagery for supporting the prevention of forest fires and the recovery/ damage assessment of burnt area. The present paper presents an improved version of one of the products developed under the PREFER project, which is the Daily Fire Hazard Index (DFHI).
\end{abstract}

Keywords: Satellite, hazard, fire, optical imagery.

\section{RESUMO}

Em dezembro de 2015, após 3 anos de atividade, o projeto FP7 PREFER (acrónimo de Space-based Information Support for Prevention and REcovery of Forest Fires Emergency in the MediteRranean Area) foi concluído. 0 projeto propunha-se a dar resposta à necessidade de melhorar a utilização de imagens de satélite em aplicações relacionadas com serviços de emergência e, em particular, com os incêndios florestais. O projeto teve como principal objetivo o desenvolvimento, validação e demonstração de produtos baseados em imagens ópticas e de radar (SAR - Synthetic Aperture Radar) para apoio à prevenção de incêndios florestais, à avaliação de danos e recuperação de áreas ardidas. Este artigo apresenta um dos produtos desenvolvidos no âmbito do projeto PREFER, numa versão aperfeiçoada, designadamente o Índice Diário de Perigo de Incêndio (DFHI - Daily Fire Hazard Index).

Palavras-chave: Satélite, perigo, incêndio, imagens ópticas.

\footnotetext{
* O texto deste artigo corresponde a uma comunicação apresentada no IV Congresso Internacional de Riscos, tendo sido submetido em 25-08-2017, sujeito a revisão por pares a 22-09-2017 e aceite para publicação em 13-11-2017. Este artigo é parte integrante da Revista Territorium, n. ${ }^{\circ} 26$ (I), 2019, ${ }^{\circ}$ RIscos, ISSN: 0872-8941.
} 
Introduction

In December 2015, after 3 year of activity, the FP7 project PREFER (Space-based Information Support for Prevention and REcovery of Forest Fires Emergency in the MediteRranean Area) reached the end (G. Laneve et al., 2016a). However, project partners (see TABLE I) were requested to continue to provide users with the project products even during summer 2016. The main purpose of PREFER was to set up a common infrastructure to provide mapping tools and services, adapted to the needs of end-users working in distinct stages of forest fire management. Therefore, the project aimed at developing, validating and demonstrating information products based on optical and SAR (Synthetic Aperture Radar) imagery for supporting prevention and recovery/ damage assessment of forest fires. To attain this goal, the project was driven by three main conditions:

1) The development of a common framework regarding fire prevention and recovery, applicable to European Mediterranean countries;

2) The creation of a service available at the operational level and useful for multiple users from different sectors;

3) The timely delivery of easily-accessible cartographic tools, based on harmonized, high-quality and up-todate information.

The present paper aims at presenting an improved version of one of the products developed in the framework of the PREFER project, that is, the Daily Fire Hazard Index (DFHI) (G. Laneve et al., 2016b).
The computation of the Daily Fire Hazard Index (DFHI), is obtained starting from the calculation of the FPI (Fire Potential Index) that is based on the relationship provided by some authors (R. Burgan et al., 1998; A. Lopez et al., 2002; J. San-Miquel et al., 2003).

The estimate processing of the current version of the DFHI involves the following steps:

1) The availability of a fuel map of the area of interest;

2) The computation of the Relative Greenness based on daily revisit frequency sensors (MODIS);

3) The introduction of the meteorological data;

4) Computation of the DFHI for three days by using meteo data of the actual day and the next two days;

5) Correction of the live vegetation contribution to fueling the fire by introducing the vegetation water content;

6) Correction of the DFHI by introducing the effect of the solar illumination conditions.

In Europe, updated information of fire hazards are daily provided by the JRC EFFIS (Joint Research Centre, European Forest Fire Information System) system (J. San-Miguel-Ayanz et al., 2003). However, the current version of DFHI has a spatial resolution of 250 meters, whereas the FWI (Fire Weather Index) provided by EFFIS has a $10 \mathrm{~km}$ spatial resolution.

The enhanced version of the DFHI, described in this paper contemplates: an improved spatial resolution using high resolution images (Landsat 8 and Sentinel 2),

TABLE I - List of the PREFER partners and the products for which they are responsible.

TABELA I - Lista dos parceiros do PREFER e os produtos sob sua responsabilidade.

\begin{tabular}{|c|c|l|}
\hline PREFER Partners & $\begin{array}{c}\text { Short Name/ } \\
\text { Country }\end{array}$ & \multicolumn{1}{|c|}{ Products responsibility } \\
\hline Scuola di Ingegneria Aerospaziale & SIA/Italy & $\begin{array}{l}\text { Project Coordination, fire Hazard, fire prescribed } \\
\text { maps \& Damage Assessment }\end{array}$ \\
\hline IES Consulting & IES/Italy & Vegetation recovery \& burned areas delineation \\
\hline $\begin{array}{c}\text { Compagnia Generale per lo Spazio } \\
\text { S.P.A }\end{array}$ & CGS/Italy & $\begin{array}{l}\text { Service Infrastructure Design, Development, } \\
\text { Integration \& Testing }\end{array}$ \\
\hline $\begin{array}{c}\text { GMV AEROSPACE AND DEFENCE SA } \\
\text { diktyakon kai tilepikinoniakon } \\
\text { efarmoggon etaira periorismenis } \\
\text { efthinis epe }\end{array}$ & GMV/Spain & Space Segment Analysis; Fuel map \& fire risk map \\
\hline $\begin{array}{c}\text { Center of Security Studies } \\
\text { University of Strasburg }\end{array}$ & KEMEA/Greece & $\begin{array}{l}\text { Mobile Applications Design, Development, } \\
\text { Integration \& Testing; User Training \& Workshops } \\
\text { and Appraisal }\end{array}$ \\
\hline University of Coimbra & UCO/Portugal & Service Validation and Fire vulnerability map \\
\hline
\end{tabular}


the introduction of the wind effects in the estimation of the dead vegetation moisture water content, the introduction of further elements in the product processing chain (estimate of the fire Rate of Spread, ROS). The results, in terms of improvement of the high fire hazard areas identification, will be discussed.

The DFHI, represents an advanced version of the FPI (Fire Potential Index) aiming at adapting this index, originally developed for United States (R. Burgan et al., 1998), to Euro-Mediterranean conditions (A. López et al., 2002).

The idea to develop maps able to show the fire risk/ hazard is based on the observation that there is a tight relationship between the fire and the characteristics of the fuel (vegetation type, density, humidity content), the topography (slope, altitude, solar aspect angle) and the meteorological conditions (rainfall, wind direction and speed, air humidity, surface and air temperature). These parameters directly impact the proneness of a given area to the fire ignition and propagation. Since these quantities can be measured, notwithstanding the cause of the fire ignition, mainly due, in the Mediterranean area, to human actions (more than $90 \%$ of the ignitions is intentional or accidental), could be unpredictable, the behavior of the fire can be considered strictly dependent from those and then it can be foreseen when such parameters are known. In general, according to the model adopted, the methods of fire risk estimate exploit different information and can be distinguished as follows (G. Laneve et al., 2007):

"Statistical methods or Structural (long-term fire risk index) defining forecast models based on the utilization of slowly changing parameters like topography or other variables that can be considered constant along the year and statistical information on the frequency of the phenomenon".

Dynamical Methods (short-term fire risk index) based on data measured continuously (i. e. daily), on characteristics territorial data (orography and vegetation) and on forecast models of the meteorological parameters.

Indices like: Fire Probability Index and the Likely Damage Index belong to the first category. The Fire Probability Index defines the fire probability by taking into account three parameters: the fuel available, the topography and a socio-economical variable. The Likely Damage Index provides an estimate of the possible damage that a fire can cause in a given area. This index can be evaluated taking into account: soil erosion proneness, slope and rainfall amount, protection level based on the environmental interest and distance from houses that allows to consider the risk for human live and his properties. On the other side, the short-term fire indices are, in general, able to provide information on the danger of the event defining: areas of possible ignition, propagation direction and speed, irradiated energy, etc.
In its simplest form these models provide hazard index. Such an index represents the probability of the ignition and propagation of the forest fire. According to this index, a daily level of risk can be defined. The different indices used for generating maps of fire risk are, in general, based on the following meteorological parameters: air temperature and humidity, wind speed, rainfall in the previous 24 hours, cloudiness, solar radiation during the previous 24 hours, averaged monthly temperature, maximum and minimum temperature during the previous 24 hours. By combining this daily fire hazard index with the information typical of the Likely Probability Index (infrastructures, protected areas, etc.) a Fire Vulnerability Index can be computed.

The European Commission funded the development of the EFFIS (European Forest Fires Information System) system (J. San-Miguel Ayanz et al., 2003). This system, developed by JRC (Joint Research Centre), provides, apart from a structural risk index already re-called above, a three days forecast based on a daily updated risk index. For several years the forecast has been based on 7 different indices (6 of them represent an evolution of indices developed for national application and they are basically meteorological indices), namely: the Portuguese index (INMG, 1988), the ICONA Method (ICONA; 1993), the numerical risk Drouet-Sol (J. Drouet et al., 1993), the Italian index of risk (F. Ventura et al. 2001), the Canadian Fire Weather Index (K. Heidorn, 1998), the BEHAVE Model (R. Rothermel et al., 1986), the Fire Potential Index (FPI) (R. Burgan et al., 1993; R. Burgan et al., 1998). Satellite data are used for the computation of only one of these 7 indices (the FPI). After the test period, the JRC has adopted, as method to assess the fire hazard level, the Canadian Forest Fire Weather Index (FWI) System. Based on such index, fire danger is mapped in 6 classes (very low, low, medium, high, very high and extreme) with a spatial resolution of about $16 \mathrm{~km}$ (ECMWF data) and $10 \mathrm{~km}$ (MF data). The FWI is based exclusively on meteorological data.

Conversely, the FPI uses both static and dynamic variables from three data sources: fuel type maps, satellite sensor images, and meteorological data, to derive what is referred to as fire potential. This model is based on the one developed by Burgan et al. (1998).

The FPI consists in the estimate of the fuel conditions (H. Anderson, 1982) by means of a separation of the dead and green vegetation. This estimate is carried out by using maps of the vegetation index NDVI (Normalized Digital Vegetation Index) (N. Gobron et al., 2000) obtained with space-borne sensor like, for instance, MODIS (on board of the Terra and AQUA satellites) (A. Huete et al., 2002). To carry out the computation, a map of the fuel distribution on the area of interest is needed. Other needed quantities are: the air temperature and 
humidity, cloudiness and rainfall. This index, commonly called integrated or advanced, is based on the FPI derived by Burgan (R. Burgan et al., 1998) for U.S. and successfully validated in California. Its validation in the European context has not yet completed. The model requires the NDVI to compute the Relative Greenness, meteorological data (air temperature, relative humidity, cloudiness and rainfall) for estimating the Ten Hours Time Lag Fuel Moisture (FM10hr) (R. M. Nelson, 2000) and a fuel map to estimate the percentage of dead vegetation. The relative greenness (RG) or vegetation stress index represents how much green is a pixel, with reference to the range of historical observation of the NDVI used (R. Burgan et al., 1993). This quantity allows the estimate of the percentage of green fuel, as function of the fuel model assigned to each pixel.

The Ten Hours Time Lag Fuel Moisture (FM10hr) has been selected as the quantity representative of the humidity available in the dead vegetation (R. M. Nelson, 2000). Such a quantity can be computed by using the meteorological parameters and the relationship described by Lopez (A. Lopez et al., 2002).

The computation of the FPI, in the version that takes into account the JRC experience (Lopez et al., 2002), involves the following steps: estimate of relative greenness based on NDVI computed from MODIS images; estimate of the fuel equivalent moisture content by using meteorological data (temperature and humidity).

The version of the DFHI index developed within the PREFER project was based on MODIS images and did not take into account wind in the estimation of the ecm (equivalent moisture content) defined as the moisture present in the small dead vegetation.

The paper will present and discuss the results obtained by using higher spatial/lower temporal resolution satellite images and the new estimate of FM10hr which takes into account wind speed.

\section{Data \& Method}

The analysis concerns one of the test areas of the PREFER project, namely: Sardinia island. The target geographic area of the PREFER project was composed by all European territories located in the Mediterranean area and where fire occurrence is particularly relevant. To test and demonstrate the products and services developed, 5 smaller areas were selected based on the availability of data required to develop the products, the interest of end-users, the biophysical and social conditions of these areas and their fire occurrence history (fig. 1).

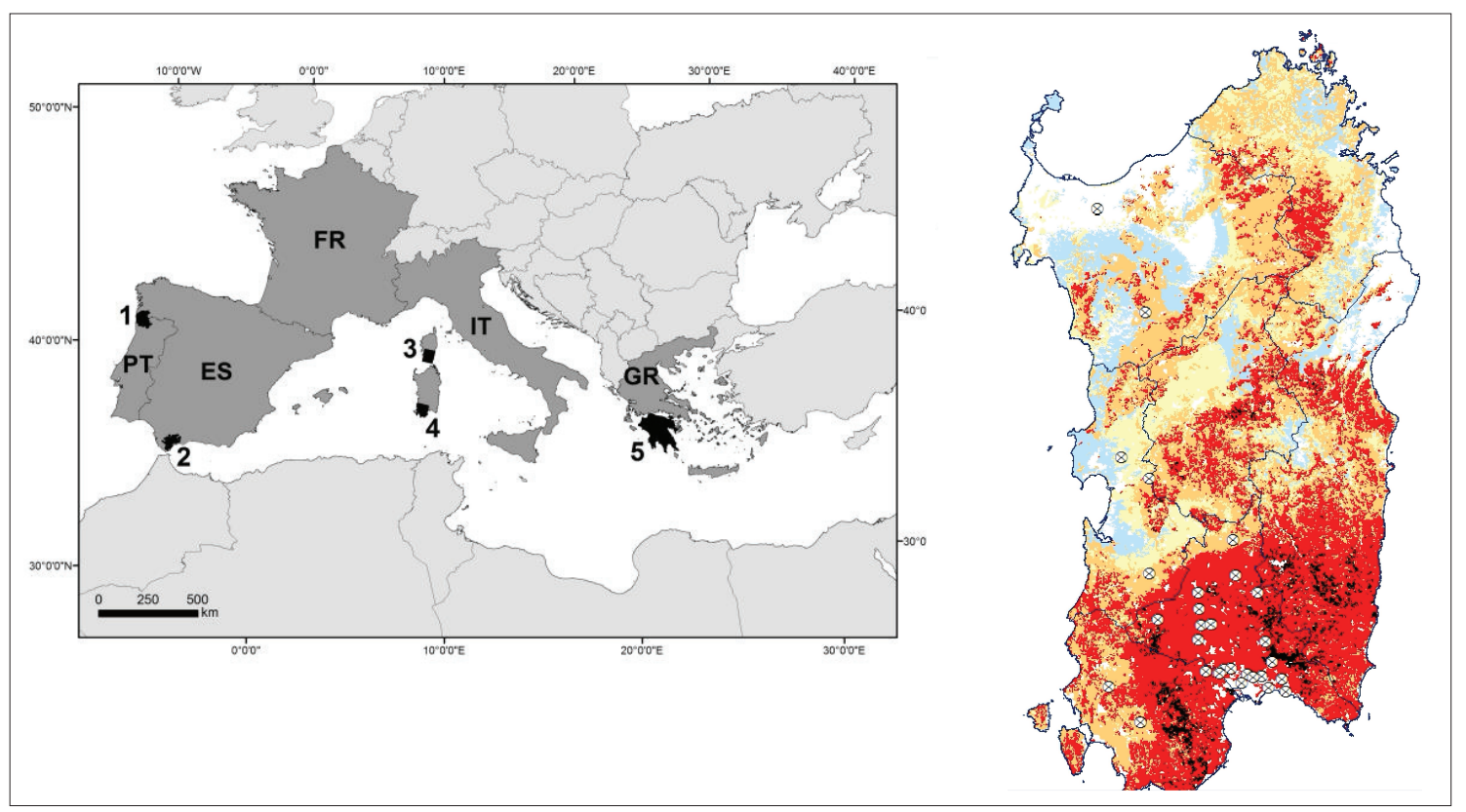

Fig. 1 - Geographic coverage of the PREFER project and location of the test areas in the participating countries. 1-Minho region, Portugal; 2-Los Alcornocales, Andaluzia, Spain; 3-SW Corsica, France; 4-SW Sardinia, Italy; 5-Peloponnese region, Greece. On the right a Daily Fire Hazard map computed for July 2015 showing that most of the fire events (white circles) occurred in the areas defined as high or very high hazard (courtesy of Sardinia Region Civil Protection).

Fig. 1 - Cobertura geográfica do projeto PREFER e localização das áreas de teste nos países participantes. 1- Região do Minho, Portugal; 2-Parque Los Alcornocales, Andaluzia, Espanha; 3-SO da Córsega, França; 4-SO da Sardenha, Itália; 5-Região do Peloponeso, Grécia. À direita, apresenta-se um mapa de perigo de incêndio diário calculado para julho de 2015, mostrando que a maioria dos incêndios (assinalados com círculos brancos) ocorreu nas áreas classificadas como perigo alto e muito alto (cortesia da Proteção Civil da região da Sardenha). 
TABLE II lists the number of fire occurrences for the 5 regions selected as test areas for the project (source JRC EFFIS reports). Concerning these areas:

- Minho region. The region covers 24 municipalities and has an area of $4.700 \mathrm{~km}^{2}$. It is characterized by a high amount of rainfall, particularly in the areas influenced by the Atlantic Ocean, contributing to the high level of biomass productivity of the region. The high biomass production, the irregular topographical conditions and the abandonment of the rural area due to recent demographic and social changes (ageing of population and migration to urban centres), favour the occurrence and propagation of forest fires; this high incidence of fires, especially in the inland municipalities, is also due to the presence of human activities (hunting, grazing) and different accessibility structures;

- Andalusia area. The area covers $523 \mathrm{~km}^{2}$ and encloses two municipalities (Cádiz and Malaga), corresponding to the Natural park of Alcornocales, a protected area. The altitude in the area ranges between 0-500 $\mathrm{m}$. The Alcornocales Park is affected by fires and requires a special effort in prevention due to its outstanding ecological value. Fires affecting the park typically originate in the border with urban areas outside the park, particularly in summer season. During the summer season, the Alcornocales Park is normally considered as "very high fire risk area", but at the same time, the cork oaks silviculture counteracts fire risk;

- Corsica region. The region, with an area of $8.680 \mathrm{~km}^{2}$ is composed by 2 departments: Corse-du-Sud and HauteCorse. Its topography ranges from 0 to $2706 \mathrm{~m}$. Its Mediterranean climate, with typical summer drought, is often tempered by altitude. This predominantly rural territory is classified as a French Regional Natural Park, due to its exceptional landscapes, natural habitats and cultural heritage, and benefits from important safeguard measures. On average, more than 500 fires burn over 1000 ha per year throughout the region. In this context, 360 municipalities are exposed to risk of forest fires, hence prevention and fight against this type of hazard is a major challenge, both to protect the public and to preserve biodiversity;
- Peloponnese region. The Greek pilot area is sited in southwest Peloponnesus and spans across five administrative units of Messinia region. It includes 29 Municipalities and hundreds of small villages and communities covering an area of $1.650 \mathrm{~km}^{2}$. The test area includes Gialova lagoon, Greece's southernmost major wetland surrounded by the natural bay of Voidokilia and featuring a significant sand-dune ecosystem. The natural vegetation covers the rough mountain relief from the sea level up to $1200 \mathrm{~m}$ in Mount Taygetos on the east. The area receives increased amount of rainfall compared to Central and Eastern parts of Greece, which leads to high forest biomass production. The climatic conditions of wet spring and prolonged dry summer are favorable to fire ignition. The strong decline of population in the region in recent decades led to the abandonment of agricultural land and to fuel accumulation. Fires occur often at the mid and low altitudes and the majority of them are linked with human activity, grazing and land use change. Although fires usually burn scrublands and shrubs at the lower altitudes, high forests of firs and black pines have burned at Mount Taygetos during the large fires of 2007;

- Sardinia region. The AOI (Area of Interest) corresponds to the footprint of a SPOT image and covers about $3000 \mathrm{~km}^{2}$. The selected area in Sardinia is an important agricultural site but it is mostly important from the ecological point of view, since it hosts several protected areas (Natura2000 areas, parks) and in particular the Monte Arcosu Forest, which is one of the bigger holm oak forest of the Mediterranean region. The altitude in the area ranges between 0-1200 m. Sardinia is one of the Italian regions more affected by fires. In fact, in 2013, it was the most affected, with 10.588 ha of area burned. The PREFER AOI comprises the provinces of Carbonia Iglesias, and parts of the provinces of Cagliari and Medio-Campidano; it includes protected areas (Monte Arcosu Forest), areas of Community interest and regional parks (Sulcis, Monte Arcu Entu, Linas-Marganai). Forest fires, frequently occurring during summer season, represent the main source of risk for the area which, for this, requires a special effort in prevention and restoration.

TABLE II - Lists of the fire events in the PREFER project test areas in the past three years.

TABELA II - Listas das ocorrências de incêndio nas áreas de teste do projeto PREFER nos últimos três anos.

\begin{tabular}{|l|c|c|c|}
\hline \multicolumn{1}{|c|}{ Region } & $\begin{array}{c}2014 \\
\text { Events/burned area [ha] }\end{array}$ & $\begin{array}{c}2015 \\
\text { Events/burned area [ha] }\end{array}$ & $\begin{array}{c}2016 \\
\text { Events/burned area [ha] }\end{array}$ \\
\hline Andalusia (SP) & $666 / 3330$ & $611 / 5499$ & $484 / 3872$ \\
\hline Corsica (FR) & $541 / 1623$ & $549 / 1647$ & $483 / 1932$ \\
\hline Minho (PT) & $3760 / 7144$ & $10003 / 34872$ & $8876 / 115639$ \\
\hline Peloponnese (GR) & $164 / 6166$ & $161 / 3388$ & $187 / 909$ \\
\hline Sardinia (IT) & $479 / 6919$ & $248 / 2573$ & $225 / 9415$ \\
\hline
\end{tabular}


Due to is relatively low spatial resolution $(250 \mathrm{~m})$, with respect to other PREFER products, the DFHI was computed for the whole Sardinia (fig. 2). The maps were computed during the 2016 summer season ( $1^{\text {st }}$ June - $30^{\text {th }}$ September). About 360 maps were computed in the period, that is three maps per day which provide the fire hazard for the present and the two following days. The DFHI maps have been computed for all the five (5) PREFER project test sites, that is: Corsica (France), Peloponnese (Greece), Sardinia (Italy), Minho (Portugal) and Andalusia (Spain). The following activities are carried out daily to elaborate the DFHI product:

- Automatic download of the most recent MODIS image of the area of interest from the USGS website;

- Automatic download of the meteorological data from Department of Meteorology of the Italian Air Force;

- Retrieval of the NDVI and EWT from MODIS images;

- Extraction of the temperature and humidity maps for the areas of interest from meteo data;

- Computation of the 15 DFHI maps (3 for each area of interest);

- $\quad$ Product upload to the PREFER dedicated ftp address.

The DFHI product has been validated both by the PREFER project team and the end users involved in the project. Concerning the Sardinia region, the regional Civil Protection carried out the validation of the DFHI maps considering the fire events occurred in a time period of three weeks in July of 2015. The results were presented at the PREFER final meeting in Cagliari in February 2016. The results, shown in fig. 1, confirm the capability of the DFHI in capturing the spatial distribution of the level of fire hazard since about the $80 \%$ of fire events occurred in areas defined at high, very high or extreme hazard. MODIS Terra and Aqua images are downloaded automatically in a systematic mode each day. An example of the downloaded images is shown in fig. 3. In particular, for covering all the PREFER project test areas 884 MODIS images (MOD02Q and MODO2H) have been downloaded from the USGS website. Apart from the daily MODIS images and meteorological information, the list of data needed to compute the DFHI comprises:

- A vegetation fuel map;

- A Digital Elevation Model;

- A historical (8 - 10 years) map of the maxima and minima NDVI for each pixel of the area of interest;

- A historical (8 - 10 years) map of the maxima and minima EWT for each pixel of the area of interest.

To compute the DFHI by using Landsat8 images a new relationship for retrieving EWT from spectral reflectances have been built. In order to estimate the relationship to be used when Landsat8 images are used we performed an extended series of simulation by using PROSAIL software. The new relationship has been computed by simulating more than two million of profiles by using PROSAIL. The results obtained by means of the simulation led to the following relationship between EWT and Landsat8 spectral reflectances:

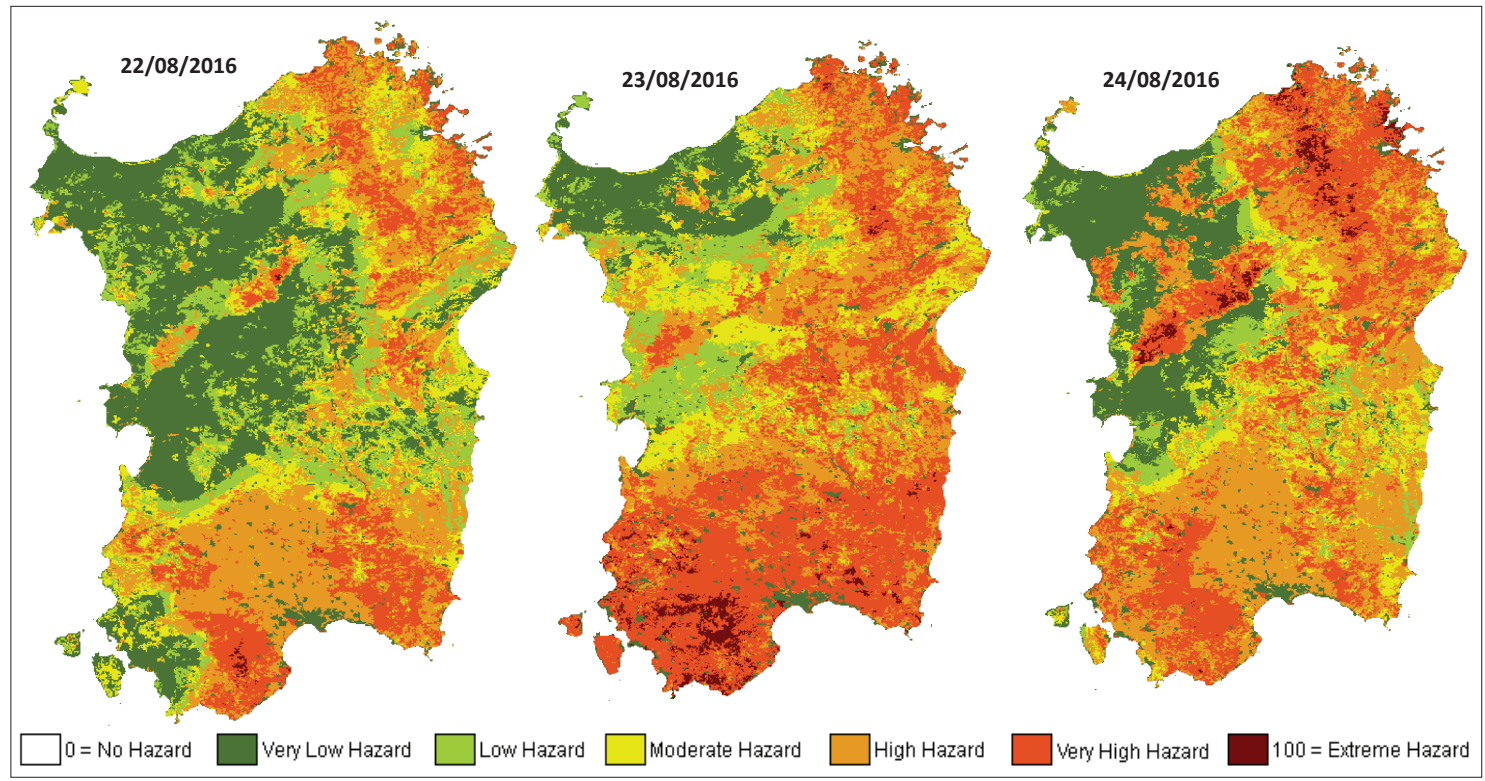

Fig. 2 - Daily hazard index maps computed for the Sardinia region in August 2016. The maps produced on 22 August 2016 depict the situation for that day and provide a prediction of fire hazard levels for the next two days (23 and 24 August 2016)..

Fig. 2 - Mapas de índice de perigo diário calculado para a região da Sardenha, em agosto de 2016. Os mapas produzidos em 22 de agosto de 2016 retratam a situação naquele dia e fornecem a previsão dos níveis de perigo de incêndio para os dois dias sucessivos 

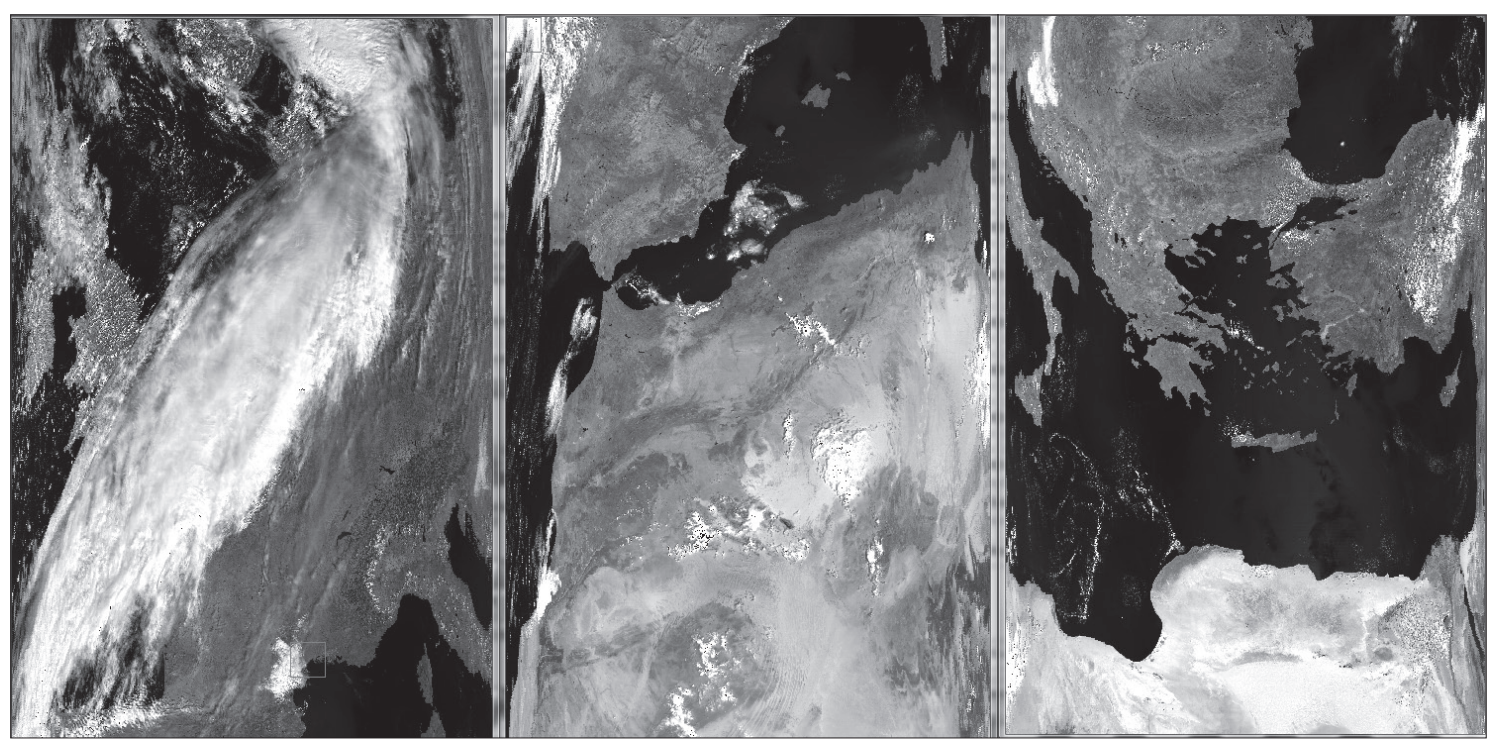

Fig. 3 - Example of the MODIS images used to compute the DFHI on 27 August 2016.

Fig. 3 - Exemplo das imagens MODIS utilizadas para calcular o DFHI para 27 de agosto de 2016.

$$
\begin{gathered}
e w t=a+b \cdot x+c \cdot y+\frac{1}{(d \cdot x+e \cdot y+f)} ; \\
x=R_{N I R} \quad ; \quad y=R_{\text {SWIR } 1}-R_{\text {SWIR } 2}
\end{gathered}
$$

where $a=-0.9573, b=0.4326, c=2.782 ; e=13.07 ; f=0.3728$ and $R_{\text {NIR }}, R_{\text {SWIR } 1}$ and $R_{\text {SWIR2 }}$ are the reflectances at 0.8 (channel 5), 1.6 (channel 6) and $2.4 \mu \mathrm{m}$ (channel 7), respectively.

The idea to enhance spatial resolution of the daily fire hazard map assumes that the vegetation status is only slightly changing during the 16-days revisit frequency characterizing Landsat8. This hypothesis is not exactly true during the summer season and, in particular, as the dry season progresses. Of course, the change of vegetation status (reflected in the NDVI values) depends also from the type of vegetation. Fig. 5 shows this behavior by comparing the differences between the values of NDVI computed 16 days apart. To simplify the analysis, it was based on the MODIS13Q1 product, that is, the NDVI averaged on 16 days of images. From the different histograms of fig. 5 related to different vegetation types and months of the summer season it can be stated:

- in June, in both forest and shrubland areas the temporal change of NDVI in the $80-90 \%$ of the pixels is lower than $5 \%$;

- in July, as the season progresses, this value tends to increase, in fact, only in $30 \%$ of cases it remains under $5 \%$ of change.
Therefore, from the histogram of fig. 4 it seems that a NDVI map computed every 16 days (L8 images refresh frequency) is not enough to catch the variability of the vegetation status during the dry and hot summer season of the South-Italy. However, this problem will be solved when both Sentinel-2 satellites will be operational because in that case the revisit frequency will be improved to 5 days.

Fig. 5 shows an example a very high spatial resolution fuel map computed by GMV in the framework of the PREFER project for a zone of the Andalusia. The map allows to underline the high spatial variability of the fuel types in the Mediterranean region. In fact, zooming in the map (fig. 5 top) it can be evidenced as in some cases a fuel map at the MODIS spatial resolution (250 $\mathrm{m}$ ) is unsuitable to represent the local variability of the vegetation (fig. 5 bottom). In the bottom image of fig. 5 a red square, corresponding to the MODIS pixel, has been superimposed to the fuel map. It is clear as, in this case, the pixel embraces several fuel types.

\section{Results}

The Ten Hours Time Lag Fuel Moisture (FM10hr) depends explicitly from the air temperature and humidity ( $R$. Burgan et al., 1998; G. Laneve et al., 2014). Such a quantity can be computed by using the meteorological parameters and the relationship described by Lopez (A. Lopez et al., 2002). In the Lopez relationship the FM10hr parameter depends explicitly by the air temperature and humidity. In order to introduce, in such parameter, the effect of wind, as already done for introducing the effect of the exposition to the sun (topography) in the estimate 


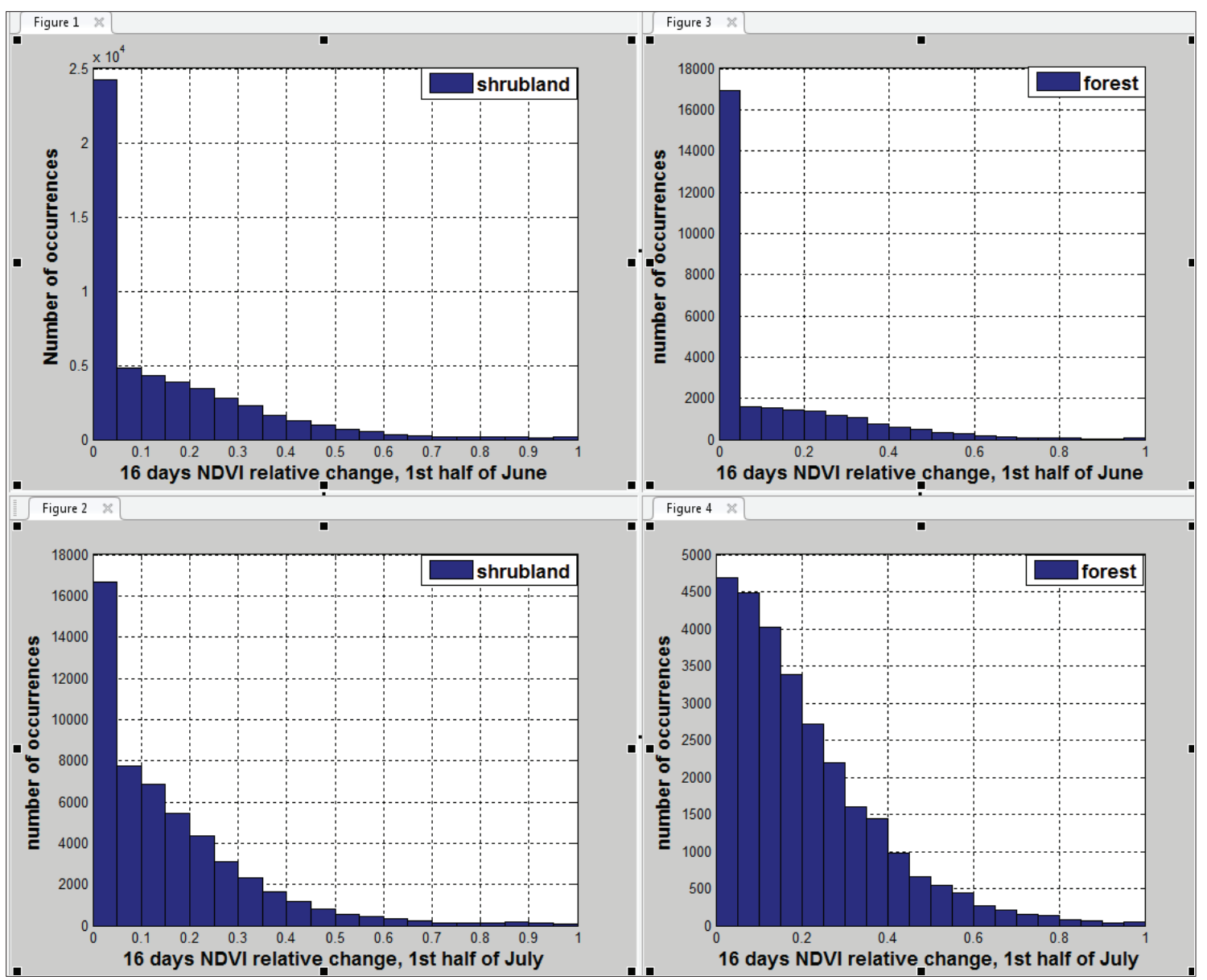

Fig. 4 - Variation of the NDVI in two weeks (revisit frequency of LandSat 8 images) in two different vegetation types and in the fire season (summer).

Fig. 4 - Variação do NDVI em duas semanas (resolução temporal das imagens Landsat8) em dois tipos diferentes de vegetação, e dois períodos da época de incêndios (durante o verão).

of the fire hazard, we exploit the evapotranspiration (ETO) relationship provided by the Penman-Monteith formula (R. G. Allen et al., 1998), modified according with FAO:

$$
E T_{0}=\frac{0.408 \cdot \Delta \cdot\left(R_{n}-G\right)+\gamma \cdot \frac{900}{T} \cdot u_{2}\left(e_{s}-e_{a}\right)}{\Delta+\gamma \cdot\left(1+0.34 \cdot u_{\gamma}\right)}
$$

where ETO is the reference evapotranspiration [mm day-1], $\mathrm{Rn}$ the net radiation available at the vegetation [MJ $\mathrm{m}-2$ day-1], $G$ the heat flux [MJ $m-2$ day-1], $T$ the daily mean temperature at $2 \mathrm{~m} \mathrm{[K]}, \mathrm{u} 2$ the wind velocity at $2 \mathrm{~m}[\mathrm{~m} \mathrm{~s}-1]$, $\mathrm{e}_{\mathrm{s}}$ water vapour saturation pressure $[\mathrm{kPa}], \mathrm{e}_{\mathrm{a}}$ actual vapour pressure $[\mathrm{kPa}], \mathrm{e}_{\mathrm{s}}-\mathrm{e}_{\mathrm{a}}$ the deficit of saturation pressure [kPa], $\Delta$ the slope of the vapour pressure curve $\left[\mathrm{kPa}{ }^{\circ} \mathrm{C}-1\right]$, $\checkmark$ psychometric constant $\left[\mathrm{kPa}{ }^{\circ} \mathrm{C}-1\right]$.

The FM10hr value, which takes into account wind speed, is computed by using eq. (2) for estimating the temperature needed to produce, with no wind, an evapotranspiration equivalent to the one produced in the actual meteorological conditions (wind $>0$ ). Fig. 6 compares the maps computed by using the meteo conditions, including wind data, of a day of August 2016, with those obtained by assuming a wind speed of $2 \mathrm{~m} / \mathrm{sec}$. The black circles highlight the areas where the difference (actual wind vs constant value of $2 \mathrm{~m} / \mathrm{sec}$ ) affects the extend of the areas defined at high or very high fire hazard.

Fig. 7 helps in justifying the development of a new fire hazard index capable to take into account the wind speed potential effect on the fire propagation. In fact, such figure confirms, what is well known from experience, the correlation existing between wind regime and burned areas. The figure compares for the 2014 summer season ( $1^{\text {st }}$ June $-31^{\text {st }}$ October) the daily maximum wind speed with the daily amount of burned areas for the Sardinia region (source http://www.sardegnageoportale.it/). As explained in the previous paragraph, to DFHI takes into account the spatial distribution of vegetation type and status. The vegetation type is defined by using the vegetation fuel types identified by JRC throughout adapting 

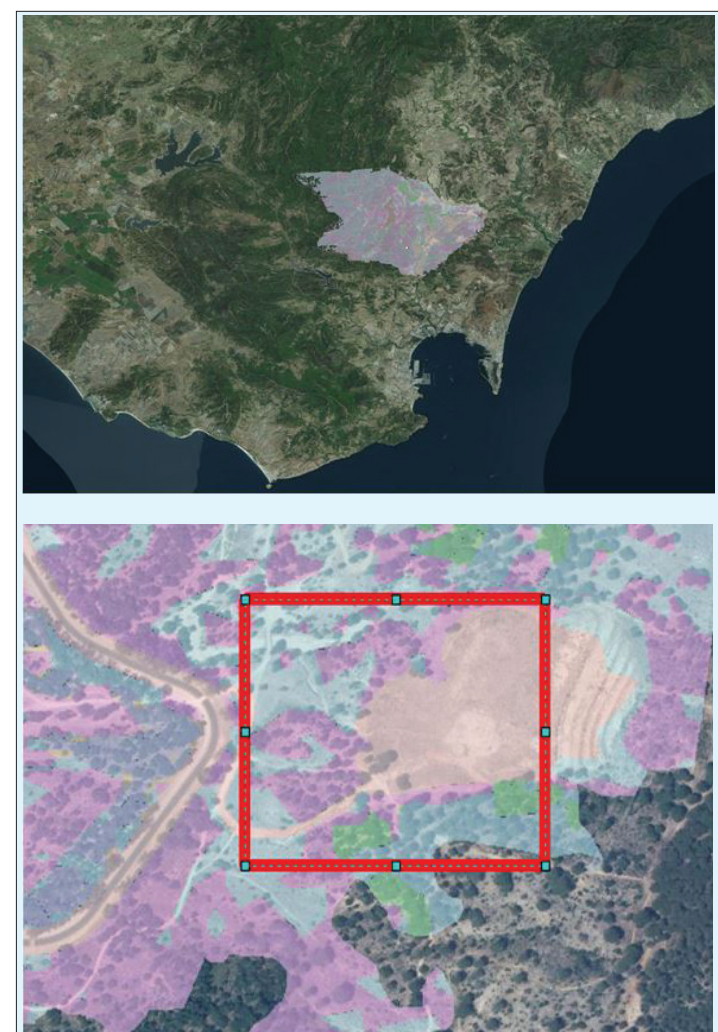

\section{Fuelmap_Andalusia LEGEND}

Azonic Fuels

Broadleaved evergreen dense fores Broadleaved evergreen open forest Broadleaved evergreen scrub forest Coniferous evergreen dense forest Coniferous evergreen open forest Coniferous evergreen scrub forest Grass

Mixed evergreen dense forest Mixed evergreen open forest Mixed evergreen scrub forest No Fuels

Non wildland fuels

Shrub

Fig. 5 - Example of the high-resolution fuel map computed by GMV (Spain) under the PREFER project for a zone of Andalusia. The lower image represents a detail of the area on which a square box corresponding to a $250 \mathrm{~m}$ MODIS image pixel has been superimposed. In this case different fuel types fall in a single MODIS pixel.

Fig. 5 - Exemplo mapa de combustível de alta resolução calculado pela GMV (Espanha) no âmbito do projeto PREFER para uma zona da Andaluzia. A imagem inferior representa um detalhe superpuesto sobre uma área quadrada correspondente a um pixel de imagem MODIS de $250 \mathrm{~m}$. Neste caso, diferentes tipos de combustível caem num único pixel MODIS.

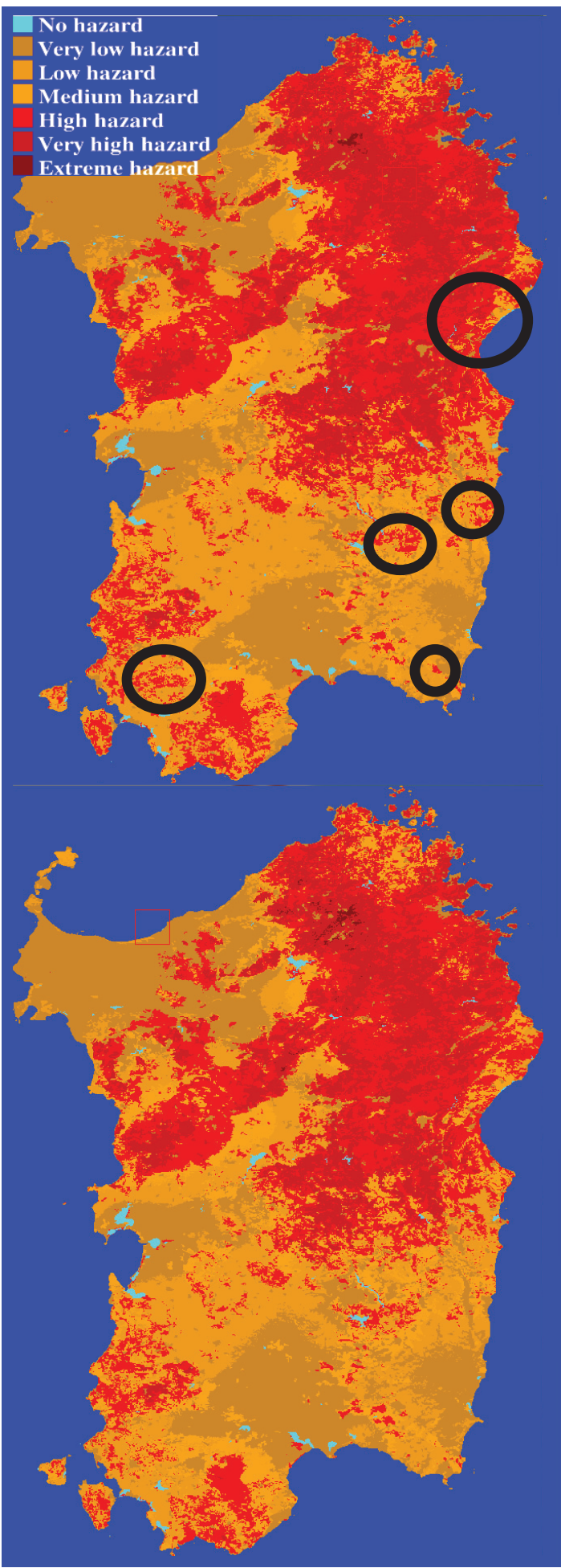

Fig. 6 - Comparison between DFHI maps computed from daily wind data (above) or assuming a constant wind speed of $2 \mathrm{~m} / \mathrm{sec}$ (below). Black circles highlight the main differences in the areas of high, very high or extreme danger.

Fig. 6 - Comparação entre os mapas DFHI calculados com dados diários de vento (imagem superior) ou assumindo um valor de velocidade de vento constante de $2 \mathrm{~m} / \mathrm{s}$ (imagem inferior).

Os círculos pretos destacam as principais diferenças nas áreas classificadas como perigo alto, muito alto ou extremo. 
the fuel types developed by Anderson for United States to the European context. The status of the vegetation is computed by estimating its greenness through a vegetation index (NDVI) computed with the temporal frequency and spatial resolution allowed by the exploited satellite sensor (daily at $250 \mathrm{~m}$ with MODIS, bi-weekly at $30 \mathrm{~m}$ with LANDSAT/OLI and every five days at $10 \mathrm{~m}$ with the Sentinel-2 constellation).

Now, more specifically, going to the better analyze the potential advantage of using high spatial resolution images (Landsat 8 in the present case), fig. 8 shows a detail of the DFHI map computed by using a Landsat8 image acquired on $3^{\text {rd }}$ of September 2016. The map computed using L8 image is compared with the one computed by using MODIS image of the same day. The MODIS based map has been resampled to 30 meters by using a nearest neighbor sampling method, that is all the $30 \mathrm{~m}$ pixels which fall in the $250 \mathrm{~m}$ pixel assume the same DFHI value of the MODIS pixel.

Superimposed on the maps are the polygons corresponding to the Class 1 of the 2012 Corine Land Cover (CLC) map. The Class 1 corresponds to Artificial Surfaces which include: urban areas (CLC code 1.1), industrial, commercial and transport units (CLC code 1.2), mines and dumps (CLC code 1.3), artificial nonagricultural vegetated areas (CLC code 1.4). Fig. 8 shows as the increased detail of the DFHI map based on Landsat8 image could be useful in detecting small areas of high fire hazard around urban areas or human assets. This information can be exploited to increase control of such areas or identify intervention areas to reduce the fuel load.
Fig.s 8 and 9 allow to state:

- The effort needed to compute daily maps of DFHI for a whole region like Sardinia could be unsuitable for the use of high resolution images. In fact, in that case the area of interest could request several days to be covered by the sensor (fig. 9) and the revisit frequency sometime could be incompatible with the rapid change of the NDVI of natural vegetation areas in summer.

- A high resolution DFHI map could be useful for monitoring/forecasting fire hazard conditions in critical areas (fig. 8) like natural parks, wild urban interface (WUI) areas, etc.

\section{Conclusion}

The paper aims at describing the progress made in the development of a daily fire hazard index capable to capture at the best the meteorological and vegetation conditions which, when a fire has been ignited negligently or deliberately, determine its propagation. The evolution of the DFHI index developed in the framework of the SIGRI and PREFER projects concerns the analysis of the possibility to produce accurate maps by using high resolution satellite images and devising a way to introduce the wind speed maintaining the definition of the fire hazard as given in R. Burgan, 1998 and A. Lopez, 2002.

Taking into account the high variability of the NDVI (vegetation greenness) during the summer period and the time span needed to completely cover, using high resolution images $(20-30 \mathrm{~m})$, a region as large as

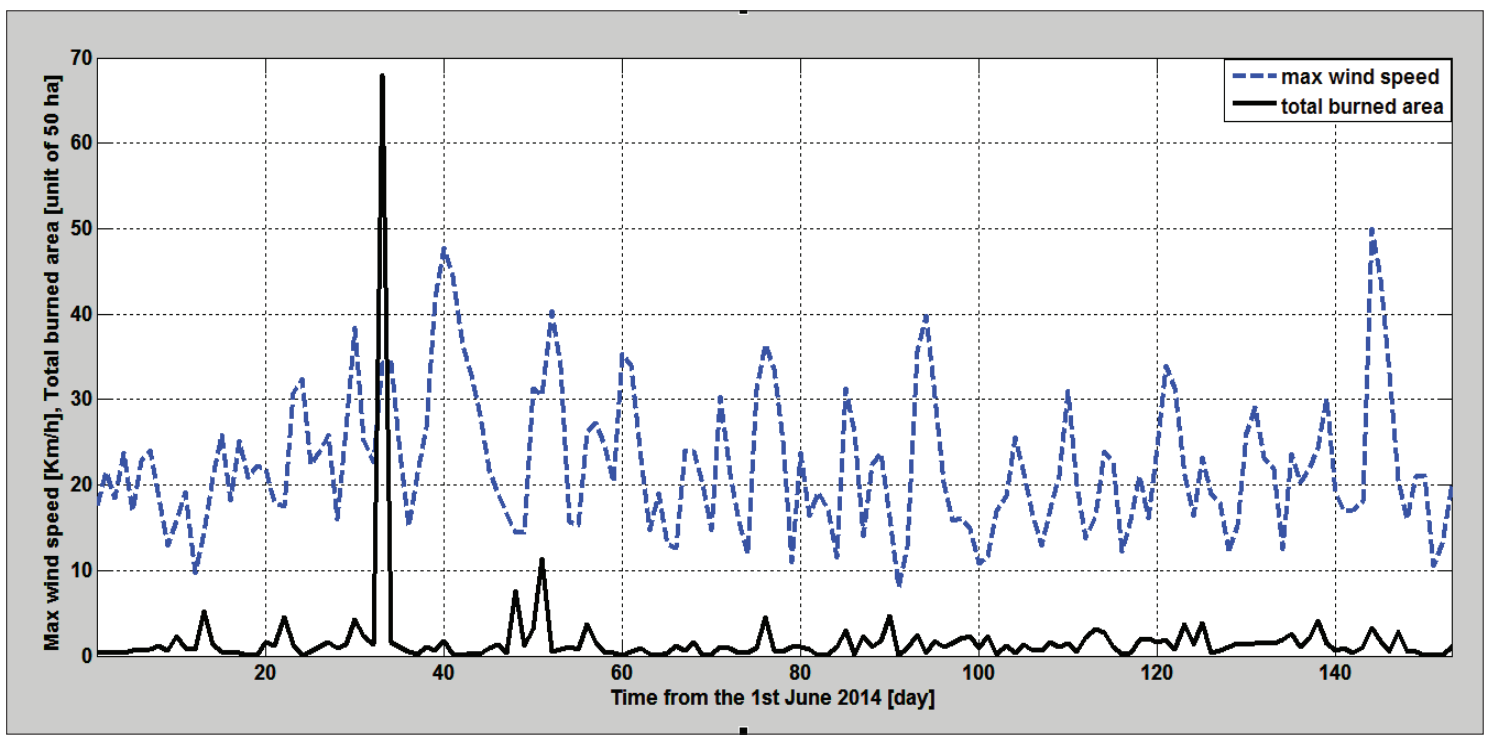

Fig. 7 - 2014 fire season. Daily comparison between the maximum wind speed in the AOI and the total burned area. As expected, there is a certain correlation. For reasons of graphic display, the total burned area [in ha] was divided by 50 .

Fig. 7 - Época de incêndios de 2014. Comparação diária entre a velocidade máxima do vento na área de teste e o total de área ardida. Verifica-se, como esperado, uma certa correlação. Por razões de visualização gráfica, o total de área ardida (em hectares) foi dividido por 50. 


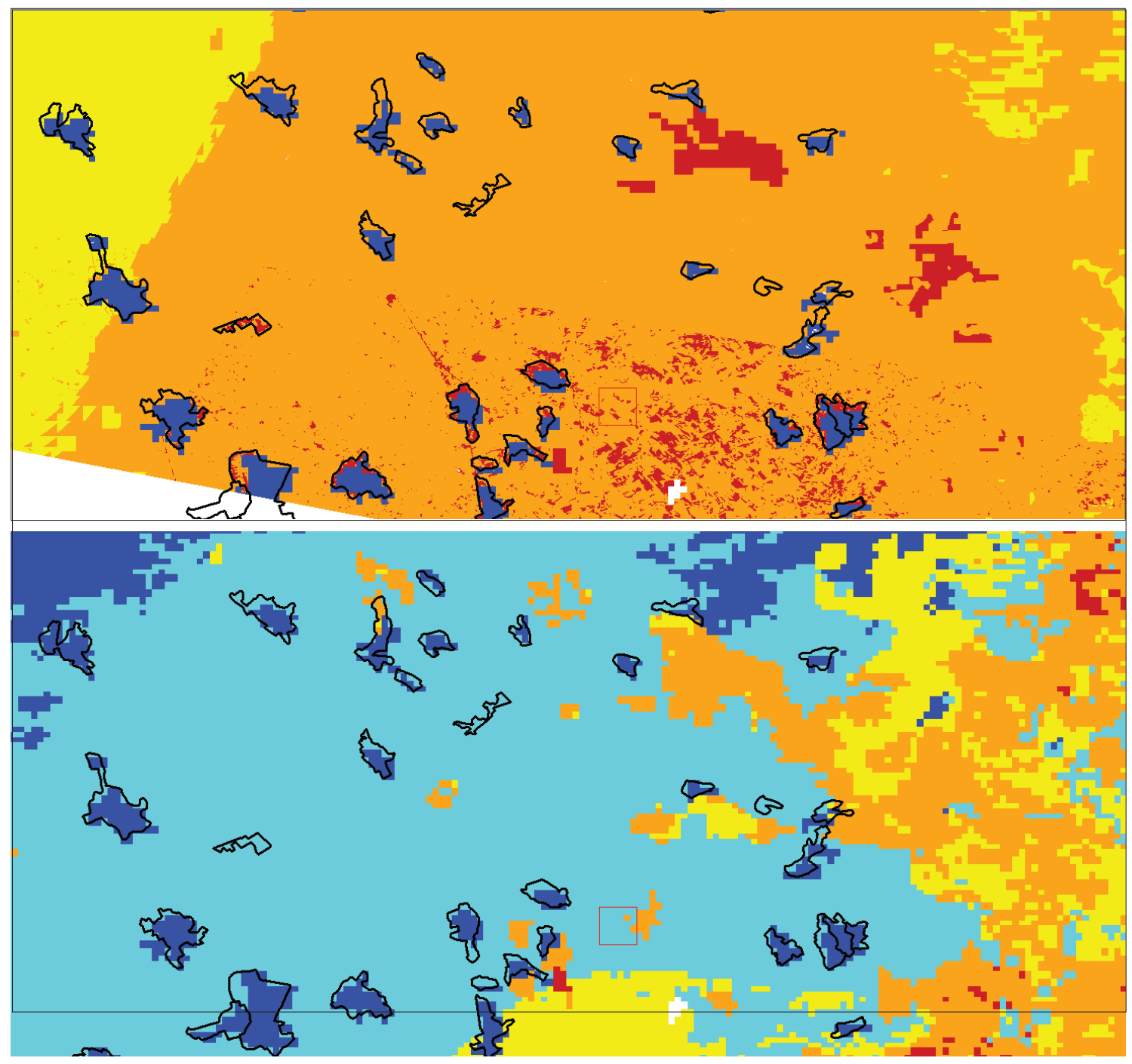

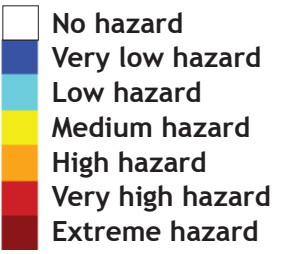

Fig. 8 - Detail of a DFHI map computed using a LandSat8 image from 3 September 2016 (above) and a MODIS image acquired the same day (below). The MODIS based map was resampled from $250 \mathrm{~m}$ to $30 \mathrm{~m}$. Black polygons represent the area corresponding to Corine Land Cover class 1 (Artificial Surfaces).

Fig. 8 - Pormenor de um mapa DFHI calculado utilizando uma imagem Landsat8 de 3 de setembro de 2016 (em cima) e uma imagem MODIS adquirida no mesmo dia (em baixo). O mapa MODIS foi redimensionado de $250 \mathrm{~m}$ para $30 \mathrm{~m}$. Os polígonos pretos representam a área correspondente à classe 1 do Corine Land Cover (Superfícies Artificiais).
Sardinia $\left(24090 \mathrm{~km}^{2}\right)$ it seems unsuitable to use a high spatial resolution DFHI. Having a $30 \mathrm{~m}$ spatial resolution DFHI could be useful to monitor/forecast fire hazard in limited areas as natural parks, protected areas and WUI zones. Possibly, using Sentinel-2 images will solve the problem of image refresh frequency, thanks to the larger sensor swath and orbit revisit frequency. However, in that case a new problem related to the dimensions (in $\mathrm{MB}$ ) of the maps (10 $\mathrm{m}$ spatial resolution) to manage will arise.

\section{References}

Allen, R. G., Pereira, L. S., Raes, D. and Smith, M. (1998). Crop evapotranspiration: guidelines for computing crop requirements. Irrigation and Drainage paper, N. 56, FAO, Rome.

Anderson, H. E. (1982). Aids to determining fuel models for estimating fire behavior. U.S. Department of Agriculture, Forest Service, Intermountain Forest and Range Experiment Station. 22. 

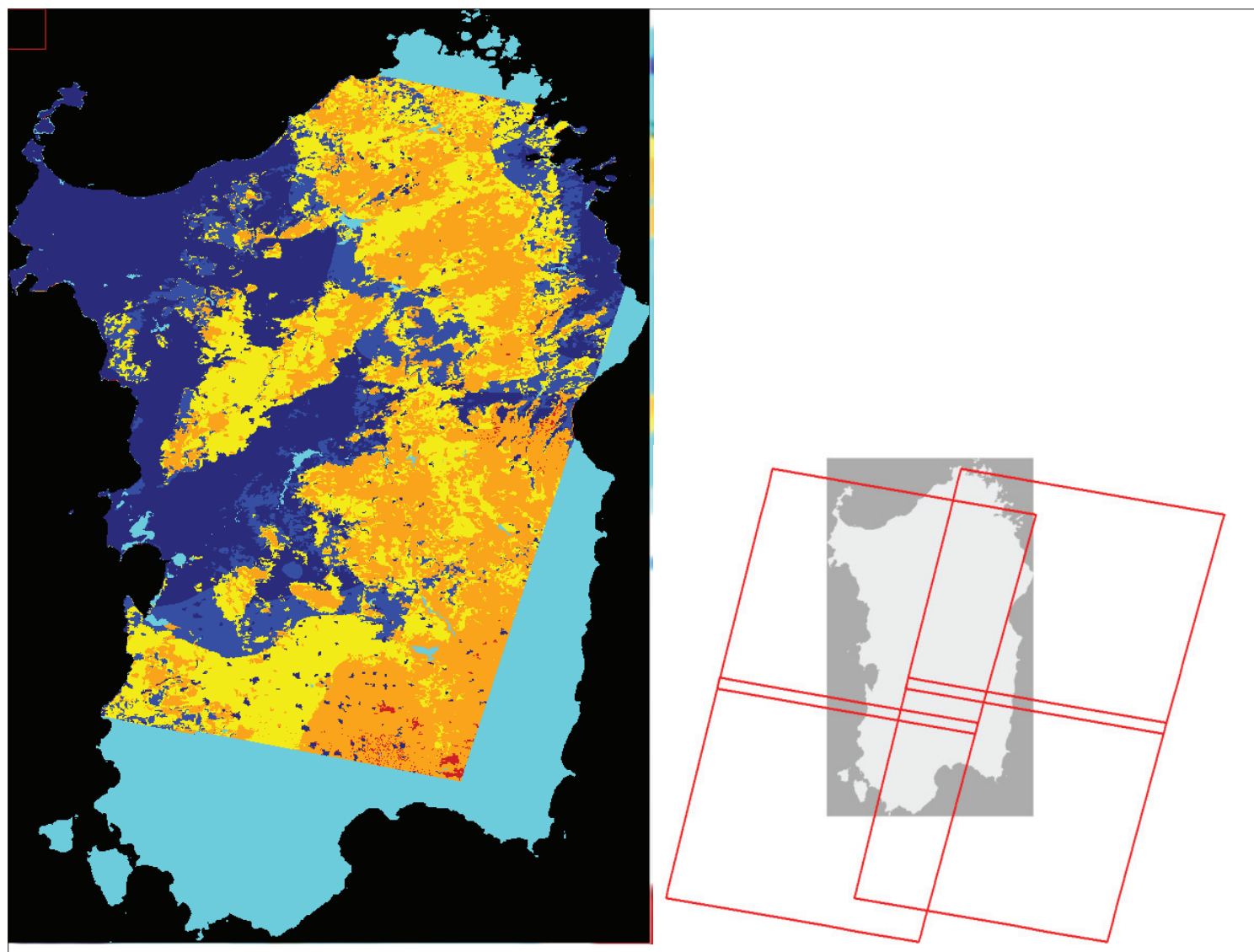

Fig. 9 - DFHI map for the area of interest computed using a single LandSat 8 image (raw 32, path 193) compared with the whole island of Sardinia (A); Footprint of the LandSat images needed to almost completely cover the Area of Interest. Due to the orbital characteristics of the satellite, there is a 7-days' gap between the acquisition of the images of the left and right parts of the area (B).

Fig. 9 - Mapa DFHI para a área de interesse, calculado usando uma única imagem Landsat 8 (raw 32, path 193) em comparação com a totalidade da ilha da Sardenha (A); Seleção das imagens Landsat necessária para cobrir quase toda a área de interesse. Devido às características orbitais do satélite, as imagens que cobrem a parte esquerda da área são adquiridas com 7 dias de diferença das imagens da parte direita $(B)$.

Burgan, R. E., Hartford, R. A. (1993). Monitoring Vegetation Greenness with Satellite data, General Technical Rep. INT-297, USDA Forest Service.

Burgan, R. E., Klaver, R.W., Klaver, J. M. (1998). Fuel models and fire potential from satellite and surface observations. Int. J. Wildland Fire, 8 (3), 159-170.

Drouet, J. C., and Sol, B. (1993). Mise au point d'un indice numerique de risque meteorologique d'incendies de forêts, Forêt Mediterranéenne 14(2), 155-162.

Heidorn, K. C. (1998). Canadian Fire Weather Index, PhD work.

Huete, A., Didan, K., Miura, T., Rodriguez, E.P., Gao, X. and Ferreira, L.G. (2002). Overview of the radiometric and biophysical performance of the MODIS Vegetation Indices. Remote Sens. Environ. 2002, 83, 195-213.

Gobron, N., Pinty, B., Verstraete, M. M., and Widlowski, J. L. (2000). Advanced vegetation indices optimized for up-coming sensors: Design, performance, and applications. IEEE Transactions on Geoscience and Remote Sensing, 38, 2489-2505.

INMG- INSTITUTO NACIONAL DE METEOROLOGIA E GEOFÍSICA (1988). Nota explicativa sobre o Indice de Risco Meteorologico de Incendios Rurais, Divisão de Meteorologia Agrìcola, Instituto Nacional de Meteorologia e Geofísica.

ICONA (1993). Manual de operaciones contra incendios forestales. Madrid, 5.1/65.

Laneve, G. and Cadau, E. (2007). Quality assessment of the fire hazard forecast based on a fire potential index for Mediterranean area by using a MSG/SEVIRI based fire detection system, Proceedings of IEEE IGARSS 2007, 2447-2450

DOI: http://doi. org/10.1109/IGARSS.2007.4423337

Laneve G., Jahjah M., Ferrucci F., Hirn B., Battazza F., Fusilli L., de Bonis R. SIGRI Project (2014). Products Validation Results, IEEE J. of Selected Topics in Applied Earth Observations and Remote Sensing. Vol. 7, 3, 895-905. 


\section{territorium 26 (I)}

Laneve, G., Bernini, G., Fusilli, L., Marzialetti, P. and Hirn, B. (2016a). Satellite-based products for supporting forest fires prevention and recovery in Europe, IEEE $16^{\text {th }}$ International Conference on Environment and Electrical Engineering (EEEIC), 1-6 DOI: http://doi. org/10.1109/EEEIC.2016.7555460

Laneve, G., Fusilli, L., and Bernini, G. (2016b). Achievements of the PREFER project in the prevention phase of the forest fire management, Proc. IGARSS 2016, 10 - 15 July 2016, Beijing, 5765-5768 DOI: http://doi. org/10.1109/IGARSS.2016.7730506

López, A., San-Miguel-Ayanz, J., Burgan, R. E. (2002). Integration of satellite sensor data, fuel type maps and meteorological observations for evaluation of forest fire risk at the pan-European scale. Int. J. Remote Sensing, 23 (13), 2713-2719.

Nelson, R. M. (2000). Prediction of diurnal change in 10-hour fuel moisture content, Canadian Journal of Forest Research 30, 1071-1087.
Rothermel, R. D. C., Wilson, R. A., Morris, G.A., Sackett, S. S. (1986). Modeling moisture content of fine dead wildland fuels: input to BEHAVE fire prediction system, USDA Forest Service, Research Paper INT-359, Intermountain Research Station, Odgen, Utah.

San-Miguel-Ayanz, J., Barbosa, P. M., Schmunk, G., Libertà, G. (2003). The European Forest Fire Information System (EFFIS). In Proceedings of the Joint Workshop of Earsel SIG and GOFC/GOLD: Innovative Concepts and Methods in Fire Danger Estimation, Belgium, June.

Ventura, F., Marletto, V., Zinoni, F. (2001). Un metodo per il calcolo dell'indice meteorologico del rischio di incendio forestale, Sherwood, Foreste e alberi oggi, 7(6), 13-16. 